Tomopterna breviceps). This increases the total count to 42 species of reptiles and nine species of amphibians in the Gir

\title{
SUPPLEMENTARY NOTE ON HERPETOFAUNA OF GIR FORETS
}

\section{Raju Vyas}

Sayaji Baug Zoo, Vadodara, Gujarat 390018, India

The Gir National Park and Sanctuary contains 37 species of reptiles and six species of amphibians, including two new records of Kollegal Ground Gecko (Geckoella collegalensis) and Brown Vine Snake (Ahaetulla pulverulenta) (Das, 1997; Vyas, 1998b; Bhatt et al., 1999). Results of further investigation on herpetofauna, added five species of reptiles (Lygosoma albopunctata, Ophisops jerdoni, Lycodon striatus, Typhlops porrectus and Psammophis leithii) and three species of amphibians (Microhyla ornata, Euphlyctis hexadactylus and

Forest.

The gecko Geckoella collegalensis (Beddome, 1870) and snake Ahatulla pulverulenta (Dumeril, Bibron \& Dumeril, 1854), are found only in the Western Ghats, southern India and Sri Lanka (Murthy, 1985; Das, 1994). Northern most distribution records of the G. collegalensis is Sanjay Gandhi National Park, Mumbai, Maharashtra (Sekar, 1994) and A. pulverulenta is Pimpri, Dangs, Gujarat (Vyas, 1988a) in Western Ghats, India. Present record of G. collegalensis (Vyas, 1998b) and A. pulverulenta from Gir Forest, Junagadh, Gujarat shows new distribution record of both species.

Distribution records of a few other vertebrates known from the Western Ghats and from Gujarat (Table 1) and above records of the two species of reptiles: G. collegalensis and A. pulverulenta from Gir forest of Gujarat, indicate the possibilities of Western Ghats fauna having extended north up to $24^{\circ}$ latitude or further more.

Table 1. List of the vertebrate animals, which shows extended distribution records from the Gujarat.

\begin{tabular}{|c|c|c|c|}
\hline & Species & Recorded locality & Source \\
\hline \multicolumn{4}{|c|}{ Mammals } \\
\hline 1. & $\begin{array}{l}\text { Rusty spotted cat } \\
\text { Felis rubiginosa }\end{array}$ & $\begin{array}{l}{ }^{1} \text { Shoolpaneshwar wildlife } \\
\text { Sanctuary, Bharuch Dist. } \\
{ }^{2} \text { Gir Forest, Junagadh Dist. }\end{array}$ & $\begin{array}{l}{ }^{1} \text { Chavan, et al., } 1991 \\
\text { 2Pathak, } 1990\end{array}$ \\
\hline \multicolumn{4}{|c|}{ Birds } \\
\hline 2. & $\begin{array}{l}\text { Malabar Crested Lark } \\
\text { Galerida malabarica }\end{array}$ & $\begin{array}{l}\text { Shoolpaneshwar Wildlife } \\
\text { Sanctuary, Bharuch Dist. }\end{array}$ & Narve et al., 1997 \\
\hline 3. & $\begin{array}{l}\text { Malabar Whisling Thrush } \\
\text { Monticola horsfieldii }\end{array}$ & $\begin{array}{l}\text { Gir National Park \& } \\
\text { Sanctuary, Junagadh Dist. }\end{array}$ & $\begin{array}{l}\text { Vyas, Rohit } \\
\text { (per. communication) }\end{array}$ \\
\hline \multicolumn{4}{|c|}{ Reptiles } \\
\hline 4. & $\begin{array}{l}\text { Gunther's Supple Skink } \\
\text { Lygosomaguentheri }\end{array}$ & $\begin{array}{l}{ }^{1} \text { Vadodara, Vadodara Dist. } \\
{ }^{2} \text { Pavagadh, Panchmahal Dist. } \\
\text { Ahemdavad Dist. }\end{array}$ & 1,2Vyas, 1998 \\
\hline 5. & $\begin{array}{l}\text { Lined Supple Skink } \\
\text { Lygosoma lineata }\end{array}$ & Kavadia, Bharuch Dist. & Naik and Vinod, 1994 \\
\hline 6. & $\begin{array}{l}\text { Roux's Forest Lizard } \\
\text { Calotes rouxii }\end{array}$ & $\begin{array}{l}\text { Shoolpaneshwar Wildlife } \\
\text { Sanctuary, Bharuch Dist. }\end{array}$ & Naik et al., 1993 \\
\hline 7. & $\begin{array}{l}\text { Nilgiri Shieldtail } \\
\text { Uropeltis ocellatus }\end{array}$ & $\begin{array}{l}\text { Shoolpaneshwar Wildlife } \\
\text { Sanctuary, Bharuch Dist. }\end{array}$ & Naik et al., 1993 \\
\hline 8. & $\begin{array}{l}\text { Flying Snake } \\
\text { Chrysopelea ornata }\end{array}$ & $\begin{array}{l}\text { Ronki, Rajkot } \\
\text { Rajkot Dist. }\end{array}$ & $\begin{array}{l}\text { S. Bhuch } \\
\text { (pers. comm., 1999) }\end{array}$ \\
\hline \multicolumn{4}{|c|}{ Amphibians } \\
\hline 9. & $\begin{array}{l}\text { Verrucose Frog } \\
\text { Limnonectes keralensis }\end{array}$ & $\begin{array}{l}\text { Shoolpaneshwar Wildlife } \\
\text { Sanctuary, Bharuch Dist. }\end{array}$ & Naik and Vinod, 1993 \\
\hline
\end{tabular}




\section{References}

Bhatt, K., R. Vyas and M. Singh (1999). Herpetofauna of Gir Protected area. Zoos' Print. 14(5): 27-30.

Chavan, S.A., C.D. Patel, S.V. Pawar, N.S. Gogate and N.P. Pandya (1991). Sighting of the rusty spotted cat Felis rubiginosa (geoffroy) in Shoolpaneshwar Sanctuary, Gujarat. J. Bombay nat. Hist. Soc. 88(1): 107-108.

Das, I. (1994). The reptiles of South Asia, checklist and distribution summary. Hamadryad, 19, 15-40.

Das, I. (1997). Resolution of the systematic status of Eublepharis macularius fuscus Borner, 1981 (Eublepharidae: Sauria: Squamata). Hamadryad 22(1): 13-20.

Murthy, T.S.N. (1985). Classification and distribution of the reptiles of India. The Snake 17: 48-71.

Naik, Y.M. and K.R. Vinod (1993). Record of the Verrucose Frog Rana keralensis (Dubois) in Shoolpaneshwar Wildlife Sanctuary (Bharuch district, Gujarat). J. Bombay nat. Hist. Soc. 90(3): 521-522. Naik, Y.M. and K.R. Vinod (1994). Records of a rare skink Lygosoma lineata (Gray, 1839) from Kevadia, Gujarat. J. Bombay nat. Hist. Soc. 91: 324-325.

Naik,Y.M., K.R. Vinod and P.K. Pradeep (1993). Reptiles of Narmada valley, Gujarat, Cobra, (11), 7-9.

Narve, D.S., C.D. Patel and N.P. Pandya (1997). Avifaunal diversity in Shoolpaneswar Sanctuary. Tiger Paper 24(1): 12-17.

Pathak, B.J. (1990). Rusty spotted cat Felis rubiginosa Geoffroy: Anew record for Gir wildlife. J. Bombay nat. Hist. Soc. 87(3): 445. Sekar, A.G. (1994). Range extension of the Spotted Forest Gecko $G$. collegalensis (Beddome, 1890). J. Bombay nat. Hist. Soc. 91(2): 323 324

Vyas, R. (1998a). Note on snakes from District Dang, Gujarat state. $J$. Bombay nat. Hist. Soc. 85(1):200.

Vyas, R. (1998b). First record of the Spotted Forest Gecko G. collegalensis (Beddome, 1870) from Gir forest, Gujarat state, India. J. Bombay Nat. Hist. Soc. 95(1): 123-124.

Butterflies are the most beautiful and colourful creatures on the earth and have a great aesthetic value. About 1500 species of butterflies are found in India (Haribal, 1992). They vary greatly in colour, habit, size and form. The exact status of butterflies particularly of northeastern regions of India are still not clearly known due to lack of proper study.

The Assam State Zoo-cum-Botanical Garden (ASZCBG) was established in 1958 , in the heart of Guwahati City $\left(26^{\circ} 11^{\prime} \mathrm{N}\right.$ and $\left.91^{\mathrm{O}} 45^{\prime} \mathrm{E}\right)$. The Zoo has a land area of about 130 ha., surrounded by two picturesque hills. The optimum temperature is $24^{\circ} \mathrm{C}$ with average rainfall of $136.43 \mathrm{~cm}$. The Zoo is designed for presenting all aspects of natural history and Animal Husbandry in an appropriate setting.

Due to its diversified habitat, butterflies from different families find representation in the Zoo campus. A study to compile the checklist of fauna and flora of the Zoo was carried out bewtween August 1996 and April 1999. Besides butterflies, 63 species of mammals, 52 species of birds and 13 species of reptiles were also recorded. Among plants, 162 species of trees and 177 species of shrubs were identified. During the survey period a total of 79 species of butterflies were recorded (Table 1), of which seven species remains unidentified. Of the 72 species identified, nine belong to the family Papilionidae, 16 to Pieridae, 29 to Nymphalidae, 13 to Lycaenidae and five species to the Family Hesperiidae. The butterfly species have been identified and verified following Haribal (1992) and Gay, et. al. (1992). Nomenclature is after Varshney (1983).

\section{Acknowledgement}

We are thankful to Mr. B.S. Bonal, Director, N.P. Kaziranga (then D.F.O., ASZCBG); Mr. R. Bhattacharjee (Present D.F.O., ASZCBG); Mrs. Rajashree Sharma, Wildlife Research Officer, ASZCBG; Dr. Jatin Kalita, Lecturer, Gauhati University and Mr. Bibhab Talukdar, Secretary General, Aaranyak Nature Club for their help and kind support. 